\title{
Modeling of syngas composition obtained from fluidized bed gasifiers using Kuhn-Tucker multipliers
}

\author{
Jordan Amaro*, Andrés Z. Mendiburu, Ivonete Ávila \\ São Paulo University (UNESP), School of Engineering, Energy Department, Guaratinguetá, SP, CEP 12510-410, Brazil
}

\section{A R T I C L E I N F O}

\section{Article history:}

Received 11 December 2017

Received in revised form

12 March 2018

Accepted 25 March 2018

Available online 26 March 2018

\section{Keywords:}

Gasification

Fluidized bed

Modified chemical equilibrium model

\begin{abstract}
A B S T R A C T
This work aims to develop a modified chemical equilibrium model to accurately determine the syngas (synthesis gas) composition obtained from fluidized bed gasifiers. In order to do so, an optimization method was applied to determine the correction factors which modify the chemical equilibrium constants, the carbon conversion efficiency and the enthalpy of reaction. The gasification agents considered for this study were: air, steam, air-steam, and air-steam-oxygen. The optimization method used the Kuhn-Tucker multipliers to obtain small RMS errors.

A total of 76 experimental compositions of syngas were selected. Among these data 60 were used to obtain correlations for the correction factor, the carbon conversion efficiency and the enthalpy of reaction. Then, a modified chemical equilibrium model was formulated by a taking advantage of these correlations.

The modified chemical equilibrium model was validated showing very good accuracy for the determination of the syngas composition, the RMS error were found to be between 0.94 and 4.84 .
\end{abstract}

() 2018 Elsevier Ltd. All rights reserved.

\section{Introduction}

Currently, gasification is one of the most widely used biomass applications [1-6]. Among the different gasifier types the fluidized bed gasifiers present several remarkable characteristics. Some of these characteristics are: good mixing between biomass and gasifying agents, low nitrogen content in syngas composition, high carbon conversion efficiency, moderate production of tars and elevated lower heating value of syngas [6]. There are two types of fluidized bed gasifiers, i.e. the bubbling and circulating fluidized bed gasifiers [4]. These gasifiers are schematically presented in Fig. 1. A detailed description of the characteristics and operation of fluidized bed gasifiers can be found in the literature [1-6].

The syngas (fuel gas obtained from gasification) composition can be basically obtained by two modelling approaches which are: chemical equilibrium modelling and kinetic modelling [4]. A chemical equilibrium model allows to calculate the concentrations of gaseous products of gasification at a given gasification temperature, these concentrations being invariable for a theoretically infinite reaction time [2]. Also, a chemical equilibrium model does not consider the geometrical characteristics of the gasifier and the

\footnotetext{
* Corresponding author.

E-mail address: jordan.amaro.gutierrez7@gmail.com (J. Amaro).
}

hydrodynamics of the mixing process between the biomass and the gasifying agents (air, steam or oxygen) [1]. On the other hand, a kinetic model is used to study the progress of chemical reactions that take place inside the gasifier, thus allowing to determine the concentrations of gaseous products at different positions along the gasifier evaluated in a given time. It takes into account the gasifier's geometry as well as its hydrodynamics [1].

In the works by Loha et al. [7] and by Karmakar et al. [8] a chemical equilibrium model (which does not consider char and tar as products) was developed. The chemical equilibrium model applied in both aforementioned works propose the solution of a system of equations. This system is constituted by the mass conservation equations of carbon, hydrogen and oxygen, and the chemical equilibrium equations of the methane formation reaction and the homogenous water-gas reaction. Subsequently, by solving this system of equations, the number of moles of the gases present in the reaction are calculated. Finally, the adjustment of the chemical equilibrium model consists of multiplying correction factors (calculated by trial and error) to the chemical equilibrium constants to evaluate the approximation of the theoretical composition of the syngas to the experimental composition, thus originating a decrease of the RMS error [9]. A chemical equilibrium model that incorporates correction factors for chemical equilibrium constants is referred to in the present research as a modified chemical equilibrium model. A modified chemical equilibrium 


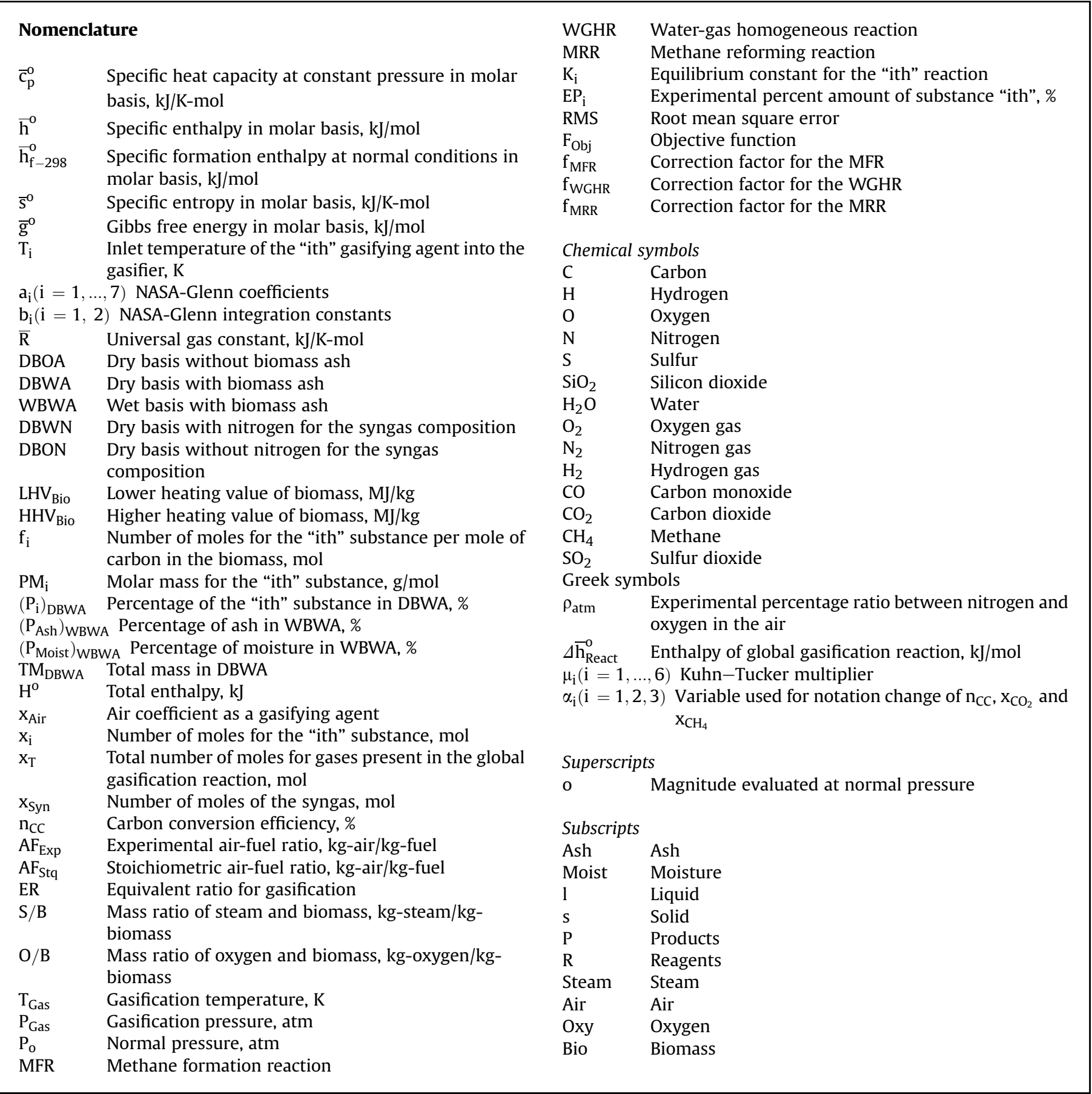

model for modeling the syngas composition is also used in other studies [10-13].

In the work by Radmanesh et al. [14] a kinetic model was developed. This model uses the hydrodynamics of the solid and gaseous phases, as well as diverse heterogeneous and homogeneous reactions. The process of pyrolysis was considered very important and two kinetic models were used for this process. These models proved to be good to estimate the composition of the syngas and its LHV. In a similar way, in the work by Zheng and Morey [15], a biphasic kinetic model was developed, that model includes the kinetics of reaction and fluid dynamics for the gasification process of corn stover. The model predicts the compositions of syngas along the gasifier and the evolution of the particles over time, under different gasification conditions. From the obtained results, it is observed that the homogenous water-gas reaction and the residence time are very influential factors in the composition of the syngas.

Thus, it was decided to use a modified chemical equilibrium model due to the simplicity of the model with respect to a kinetic model, in relation to the objective proposed in this research.

In view of the actuality of modified chemical equilibrium models, one of the main objectives of this study is to calculate in an analytical and simple way the correction factors for the chemical equilibrium constants. Another objective of this research is to calculate a theoretical syngas composition very close to the experimental one to obtain a very low value of the RMS error. In 


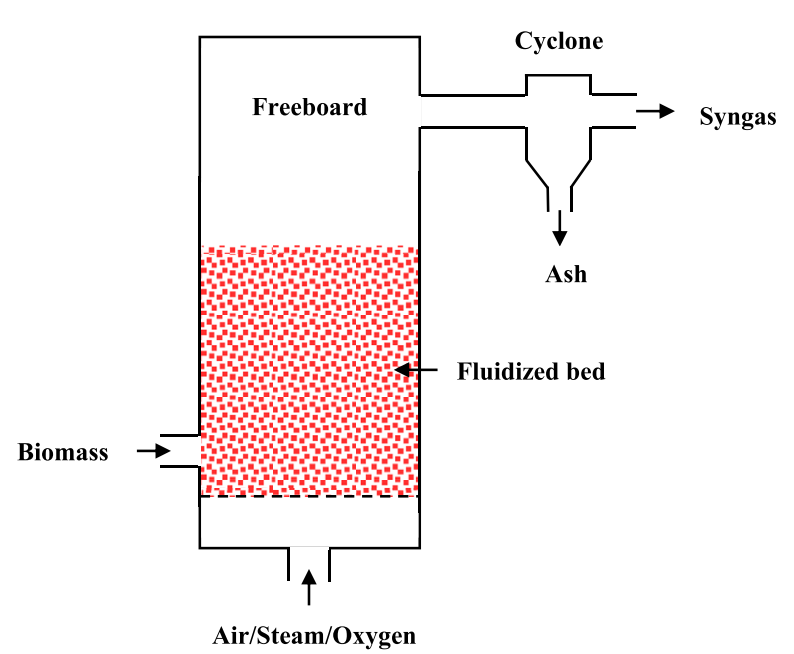

a)



b)

Fig. 1. Schematic representation of: a) bubbling fluidized bed gasifier and b) circulating fluidized bed gasifier.

addition, it is intended to consider the char, represented by $\mathrm{C}_{(\mathrm{s})}$, as a product of the gasification process. Thus, establishing a more real modified chemical equilibrium model for the gasification. On the other hand, the present investigation is relevant for the following future studies:

a) Study of the economic viability of the use of syngas in power generation systems (internal combustion engines, gas turbines or steam turbines).

b) Thermodynamic study of syngas combustion in power generation systems.

c) Study of the energy viability for the selection of a biomass based on the LHV of the syngas obtained from a fluidized bed gasifier.

d) Study of optimal gasification conditions to obtain the highest concentration of syngas components obtained from a fluidized bed gasifier.

Each of the aforementioned future studies can be carried on by using the modified chemical equilibrium model proposed for: a) Gasification with air, b) Gasification with steam, c) Gasification with air and steam, and d) Gasification with air, steam and oxygen.

\section{Determination of the correction factors}

\subsection{Biomass representation and properties}

The concentration of carbon in the biomass is important for the production of $\mathrm{CO}, \mathrm{CO}_{2}$ and $\mathrm{CH}_{4}$, since carbon is one of the reactants of the exothermic reactions (fundamental in gasification) such as the carbon combustion reaction and the methane formation reaction [6]. In addition, these reactions provide the necessary heat for endothermic reactions such as the Boudouard reaction and the heterogeneous water-gas reaction, in which carbon is also one of the reactants [4]. The content of hydrogen in the biomass is very influential in the production of $\mathrm{H}_{2}, \mathrm{CH}_{4}$ and $\mathrm{H}_{2} \mathrm{O}$ present in the syngas (on a wet basis). This is because hydrogen helps the exothermic reactions of methane formation and methane reformation [6]. The oxygen content in the biomass promotes the combustion reactions thus helping the production of $\mathrm{CO}$ and $\mathrm{CO}_{2}$. A high concentration of oxygen in the biomass helps to reduce a little the mass flow of the oxidizing agent [16].

There are different values of admissible upper limits of tar concentration for syngas applications [1]. The tars are constituted by diverse compounds among which $\mathrm{H}_{2} \mathrm{~S}, \mathrm{SO}_{2}, \mathrm{COS}, \mathrm{NH}_{3}, \mathrm{HCN}$, nitrides $\left(\mathrm{NO}_{\mathrm{x}}\right)$ are included [4]. Due to these upper limits, it is desirable that the biomasses have low concentration of sulfur and nitrogen in them.

The ash and the moisture contents of the biomass have a great influence on the production of $\mathrm{H}_{2}$ and $\mathrm{CO}$. This is because high concentrations of ash and moisture produce a great absorption of the energy supplied for gasification, as is the case of the gasification of rice husk [7,8,17-19] and of sugarcane bagasse [16] which present high concentration of ash and moisture, respectively. This energy absorption does not allow many endothermic reactions (such as the Boudouard reaction and the heterogeneous water-gas reaction) to occur inside the gasifier, thus causing the lack of $\mathrm{H}_{2}$ and $\mathrm{CO}$ production, important syngas components for use in systems of power generation [6].

In this research, the thermodynamic properties were evaluated by using the NASA-Glenn coefficients provided by McBride et al. [20]. These properties were the specific molar heat capacity at constant pressure $\left(\overline{\mathrm{c}}_{\mathrm{p}}^{\mathrm{O}}\right)$, the specific molar enthalpy $\left(\overline{\mathrm{h}}^{\mathrm{O}}\right)$ and the specific molar entropy $\left(\overline{\mathrm{s}}^{0}\right)$ of chemical substances. The aforementioned thermodynamic properties are calculating according to equations $(1)-(3)$. On the other hand, the Gibbs free energy $\left(\bar{g}^{\circ}\right)$ is obtained from the relation: $\overline{\mathrm{g}}^{\mathrm{O}}=\overline{\mathrm{h}}^{\mathrm{O}}-\mathrm{T} \overline{\mathrm{s}}^{\mathrm{O}}$.

$$
\begin{aligned}
& \bar{c}_{p}^{o}=\left(a_{1} T^{-2}+a_{2} T^{-1}+a_{3}+a_{4} T+a_{5} T^{2}+a_{6} T^{3}+a_{7} T^{4}\right) \bar{R} \\
& \bar{h}^{o}=\left(-a_{1} T^{-1}+a_{2} \ln T+a_{3} T+\frac{a_{4}}{2} T^{2}+\frac{a_{5}}{3} T^{3}+\frac{a_{6}}{4} T^{4}+\frac{a_{7}}{5} T^{5}+b_{1}\right) \bar{R}
\end{aligned}
$$

$\bar{s}^{\mathrm{o}}=\left(-\frac{\mathrm{a}_{1}}{2} \mathrm{~T}^{-2}-\mathrm{a}_{2} \mathrm{~T}^{-1}+\mathrm{a}_{3} \ln \mathrm{T}+\mathrm{a}_{4} \mathrm{~T}+\frac{\mathrm{a}_{5}}{2} \mathrm{~T}^{2}+\frac{\mathrm{a}_{6}}{3} \mathrm{~T}^{3}+\frac{\mathrm{a}_{7}}{4} \mathrm{~T}^{4}+\mathrm{b}_{2}\right) \overline{\mathrm{R}}$

The ultimate and proximate analysis of biomass are necessary in 
order to represent the biomass as a chemical formula. The ultimate analysis provides the mass concentrations of $\mathrm{C}, \mathrm{H}, \mathrm{O}, \mathrm{N}$ and $\mathrm{S}$ in the biomass, and it can be expressed in dry basis without ash (DBOA) or dry basis with ash (DBWA). The proximate analysis provides the mass concentrations of fixed carbon, volatiles, moisture and ash in the biomass, and it is generally expressed in wet basis with ash (WBWA).

There are several inorganic compounds contained in the biomass ash, because of this it is not possible to write a general chemical formula for the biomass ash. Therefore, in this work, biomass ash was assumed as being composed solely of silicon dioxide $\left(\mathrm{SiO}_{2}\right)$, as suggested by Souza-Santos [2] and applied in previous works [13,21].

In this work, the WBWA was used to express the number of moles of chemical elements in the biomass. Therefore, it was necessary to convert from DBOA or DBWA to WBWA. The expressions used to do so are presented in the supplementary material. A chemical representation of the biomass is shown in equation (4).

$$
\mathrm{CH}_{\mathrm{f}_{\mathrm{H}}} \mathrm{O}_{\mathrm{f}_{\mathrm{O}}} \mathrm{N}_{\mathrm{f}_{\mathrm{N}}} \mathrm{S}_{\mathrm{f}_{\mathrm{s}}}+\mathrm{f}_{\text {Ash }} \mathrm{SiO}_{2}+\mathrm{f}_{\text {Moist }} \mathrm{H}_{2} \mathrm{O}_{(\mathrm{l})}
$$

When the higher heating value $\left(\mathrm{HHV}_{\mathrm{Bio}}\right)$ and the lower heating value $\left(\mathrm{LHV}_{\mathrm{Bio}}\right)$ of the biomass were not available, the correlation provided by Channiwala and Parikh [22] was used to determine the $\mathrm{HHV}_{\mathrm{Bio}}$. That correlation is presented in equation (5) and provides the $\mathrm{HHV}_{\mathrm{Bio}}$ in $\mathrm{MJ} / \mathrm{kg}$. Notice that in order to use this correlation it is where the molecular mass of the biomass is given by equation (8).

$$
\mathrm{PM}_{\text {Bio }}=\mathrm{PM}_{\mathrm{C}}+\mathrm{f}_{\mathrm{H}} \mathrm{PM}_{\mathrm{H}}+\mathrm{f}_{\mathrm{O}} \mathrm{PM}_{\mathrm{O}}+\mathrm{f}_{\mathrm{N}} \mathrm{PM}_{\mathrm{N}}+\mathrm{f}_{\mathrm{S}} \mathrm{PM}_{\mathrm{S}}
$$

This expression for the molecular mass of the biomass has also been adopted in other gasification studies [7,23]. The total enthalpy of biomass is presented in equation (9).

$$
\mathrm{H}_{\mathrm{Bio}}^{\mathrm{o}}=1 \mathrm{~mol}_{\text {Bio }}\left(\overline{\mathrm{h}}_{\mathrm{f}-298}^{\mathrm{o}}\right)_{\text {Bio }}+\mathrm{f}_{\text {Ash }}\left(\overline{\mathrm{h}}_{\mathrm{f}-298}^{\mathrm{o}}\right)_{\mathrm{SiO}_{2}}+\mathrm{f}_{\text {Moist }}\left(\overline{\mathrm{h}}_{\mathrm{f}-298}^{\mathrm{o}}\right)_{\mathrm{H}_{2} \mathrm{O}_{(\mathrm{l})}}
$$

\subsection{Equilibrium modeling of the gasification process}

The gasification agents generally employed in fluidized bed gasification are steam [7,24,25], air [8,26,27], oxygen and their mixtures $[17,23,28,29]$. Consequently, the global gasification reaction proposed herein has been determined with the aim of including all commonly used gasifying agents. In the adopted global reaction, unconverted carbon $\left(\mathrm{C}_{(\mathrm{s})}\right)$ can be found in the products. Thus, a carbon conversion efficiency was included and it is represented by $n_{C C}[18,21]$. The global gasification reaction adopted in this study is presented in equation (10).

$$
\begin{aligned}
& \left(\mathrm{C}_{\mathrm{f}_{\mathrm{H}}} \mathrm{O}_{\mathrm{f}_{\mathrm{O}}} \mathrm{N}_{\mathrm{f}_{\mathrm{N}}} \mathrm{S}_{\mathrm{f}_{\mathrm{S}}}+\mathrm{f}_{\mathrm{Ash}} \mathrm{SiO}_{2}+\mathrm{f}_{\text {Moist }} \mathrm{H}_{2} \mathrm{O}_{(\mathrm{l})}\right)+\mathrm{x}_{\mathrm{Steam}} \mathrm{H}_{2} \mathrm{O}+\mathrm{x}_{\mathrm{Air}}\left(\mathrm{O}_{2}+\rho_{\mathrm{atm}} \mathrm{N}_{2}\right)+\mathrm{x}_{\mathrm{Oxy}} \mathrm{O}_{2} \\
& \longrightarrow\left(1-\mathrm{n}_{\mathrm{CC}}\right) \mathrm{C}_{(\mathrm{s})}+\mathrm{x}_{\mathrm{H}_{2}} \mathrm{H}_{2}+\mathrm{x}_{\mathrm{CO}} \mathrm{CO}+\mathrm{x}_{\mathrm{CO}_{2}} \mathrm{CO}_{2}+\mathrm{x}_{\mathrm{CH}_{4}} \mathrm{CH}_{4}+\left(\frac{\mathrm{f}_{\mathrm{N}}}{2}+\rho_{\mathrm{atm}} \mathrm{x}_{\mathrm{Air}}\right) \mathrm{N}_{2} \\
& +\mathrm{x}_{\mathrm{H}_{2} \mathrm{O}} \mathrm{H}_{2} \mathrm{O}+\mathrm{f}_{\mathrm{S}} \mathrm{SO}_{2}+\mathrm{f}_{\mathrm{Ash}} \mathrm{SiO}_{2}
\end{aligned}
$$

necessary to express the biomass in DBWA.

$$
\begin{gathered}
\mathrm{HHV}_{\text {Bio }}=0.3491\left(\mathrm{P}_{\mathrm{C}}\right)_{\mathrm{DBWA}}+1.1783\left(\mathrm{P}_{\mathrm{H}}\right)_{\mathrm{DBWA}}+0.1005\left(\mathrm{P}_{\mathrm{S}}\right)_{\mathrm{DBWA}}- \\
0.1034\left(\mathrm{P}_{\mathrm{O}}\right)_{\mathrm{DBWA}}-0.0151\left(\mathrm{P}_{\mathrm{N}}\right)_{\mathrm{DBWA}}-0.0211\left(\mathrm{P}_{\mathrm{Ash}}\right)_{\mathrm{DBWA}}
\end{gathered}
$$

for:

$$
\begin{aligned}
& 0.00 \% \leq\left(\mathrm{P}_{\mathrm{C}}\right)_{\mathrm{DBWA}} \% \leq 92.25 \% \\
& 0.43 \% \leq\left(\mathrm{P}_{\mathrm{H}}\right)_{\mathrm{DBWA}} \% \leq 25.15 \% \\
& 0.00 \% \leq\left(\mathrm{P}_{\mathrm{O}}\right)_{\mathrm{DBWA}} \% \leq 50.00 \% \\
& 0.00 \% \leq\left(\mathrm{P}_{\mathrm{N}}\right)_{\mathrm{DBWA}} \% \leq 5.60 \% \\
& 0.00 \% \leq\left(\mathrm{P}_{\mathrm{S}}\right)_{\mathrm{DBWA}} \% \leq 94.08 \% ; \\
& 0.00 \% \leq\left(\mathrm{P}_{\mathrm{Ash}}\right)_{\mathrm{DBWA}} \% \leq 71.40 \% ; \\
& 4.745 \mathrm{MJ} / \mathrm{kg} \leq \mathrm{HHV}_{\text {Bio }} \leq 55.345 \mathrm{MJ} / \mathrm{kg}
\end{aligned}
$$

In order to apply the First Law of Thermodynamics, the enthalpy of formation of the biomass must be known, it can be determined by using equation (7).
The parameter $\rho_{\text {atm }}$ represents the number of moles of nitrogen per mole of oxygen on the air. In this research, nitrogen and oxygen percentages were assumed to be $79 \%$ and $21 \%$, respectively, this assumption implies that $\rho_{\text {atm }}=3.76$.

When air is the gasification agent, the gasification equivalence ratio (ER) is used. The ER is defined as the ratio of the experimental air-fuel ratio to the stoichiometric air-fuel ratio, $\mathrm{ER}=\mathrm{AF}_{\mathrm{Exp}} / \mathrm{AF}_{\mathrm{Stq}}$. Therefore, the coefficient of the air used in the gasification is defined in the equation (11).

$\mathrm{x}_{\text {Air }}=\mathrm{ER}\left(1+\mathrm{f}_{\mathrm{S}}+\frac{\mathrm{f}_{\mathrm{H}}}{4}-\frac{\mathrm{f}_{\mathrm{O}}}{2}\right)$

When steam is the gasification agent, the steam to biomass ratio (S/B) is used. Therefore, the number of moles of steam can be obtained from equation (12).

$\mathrm{S} / \mathrm{B}=\frac{\mathrm{X}_{\text {Steam }} \mathrm{PM}_{\mathrm{H}_{2} \mathrm{O}}}{\mathrm{PM}_{\text {Bio }}}$

$$
\begin{aligned}
\left(\overline{\mathrm{h}}_{\mathrm{f}-298}^{\mathrm{o}}\right)_{\mathrm{Bio}} & =\mathrm{HHV}_{\mathrm{Bio}} \mathrm{PM}_{\mathrm{Bio}}+\left(\frac{1 \mathrm{~mol}_{\mathrm{CO}_{2}}}{1 \mathrm{~mol}_{\mathrm{Bio}}}\right)\left(\overline{\mathrm{h}}_{\mathrm{f}-298}^{\mathrm{o}}\right)_{\mathrm{CO}_{2}}+\left(\frac{\mathrm{f}_{\mathrm{H}}}{2 \mathrm{~mol}_{\mathrm{Bio}}}\right)\left(\overline{\mathrm{h}}_{\mathrm{f}-298}^{\mathrm{o}}\right)_{\mathrm{H}_{2} \mathrm{O}_{(\mathrm{l})}} \\
& +\left(\frac{\mathrm{f}_{\mathrm{S}}}{1 \mathrm{~mol}_{\mathrm{Bio}}}\right)\left(\overline{\mathrm{h}}_{\mathrm{f}-298}^{\mathrm{o}}\right)_{\mathrm{SO}_{2}}
\end{aligned}
$$


When oxygen is the gasification agent, the ratio of oxygen mass flow rate to biomass mass flow rate $(\mathrm{O} / \mathrm{B})$ is used. This ratio is defined in equation (13).

$\mathrm{O} / \mathrm{B}=\frac{\mathrm{PM}_{\mathrm{O}_{2}}\left(\dot{\mathrm{V}}_{\mathrm{Oxy}} / 22.4\right)}{\dot{\mathrm{m}}_{\text {Bio }}}$

Where $\dot{\mathrm{V}}_{\text {Oxy }}$ is the volumetric flow rate of oxygen in $\mathrm{Nm}^{3} / \mathrm{h}$, $\dot{\mathrm{m}}_{\text {Bio }}$ is the mass flow rate of biomass in $\mathrm{kg} / \mathrm{h}$, and $22.4 \mathrm{~m}^{3}$ is the volume occupied by $1 \mathrm{kmol}$ of an ideal gas at normal pressure and temperature conditions. Therefore, the number of moles of oxygen can be determined by equation (14).

$\mathrm{X}_{\mathrm{Oxy}}=\frac{(\mathrm{O} / \mathrm{B}) \mathrm{PM}_{\mathrm{Bio}}}{\mathrm{PM}_{\mathrm{O}_{2}}}$

Once the global gasification reaction has been adopted and the number of moles of the reactants have been determined, the Law of Mass Conservation was applied to each chemical element in the reaction. After some algebraic manipulations, the expressions shown in equations (15) - (18) were obtained. The total number of moles of the gaseous products $\left(\mathrm{x}_{\mathrm{T}}\right)$ is given by equation (18).

$\mathrm{x}_{\mathrm{CO}}=\mathrm{n}_{\mathrm{CC}}-\mathrm{x}_{\mathrm{CO}_{2}}-\mathrm{x}_{\mathrm{CH}_{4}}$

$\mathrm{x}_{\mathrm{H}_{2}}=\mathrm{C}_{\mathrm{H}_{2}}+\mathrm{n}_{\mathrm{CC}}+\mathrm{x}_{\mathrm{CO}_{2}}-3 \mathrm{x}_{\mathrm{CH}_{4}}$

$\mathrm{x}_{\mathrm{H}_{2} \mathrm{O}}=\mathrm{C}_{\mathrm{H}_{2} \mathrm{O}}-\mathrm{n}_{\mathrm{CC}}-\mathrm{x}_{\mathrm{CO}_{2}}+\mathrm{x}_{\mathrm{CH}_{4}}$

$\mathrm{x}_{\mathrm{T}}=\mathrm{C}_{\mathrm{T}}+\mathrm{n}_{\mathrm{CC}}-2 \mathrm{x}_{\mathrm{CH}_{4}}$

where $\mathrm{C}_{\mathrm{H}_{2}}, \mathrm{C}_{\mathrm{H}_{2} \mathrm{O}}$ and $\mathrm{C}_{\mathrm{T}}$ are input parameters that depend only on the reactants:

$\mathrm{C}_{\mathrm{H}_{2}}=\frac{\mathrm{f}_{\mathrm{H}}}{2}-\mathrm{f}_{\mathrm{O}}-2 \mathrm{x}_{\mathrm{Oxy}}-2 \mathrm{x}_{\mathrm{Air}}+2 \mathrm{f}_{\mathrm{S}}$

$\mathrm{C}_{\mathrm{H}_{2} \mathrm{O}}=\mathrm{f}_{\mathrm{O}}+\mathrm{f}_{\text {Moist }}+2 \mathrm{x}_{\mathrm{Oxy}}+\mathrm{x}_{\text {Steam }}+2 \mathrm{x}_{\text {Air }}-2 \mathrm{f}_{\mathrm{S}}$

$\mathrm{C}_{\mathrm{T}}=\frac{\mathrm{f}_{\mathrm{H}}}{2}+\mathrm{f}_{\text {Moist }}+\mathrm{x}_{\text {Steam }}+\frac{\mathrm{f}_{\mathrm{N}}}{2}+\rho_{\mathrm{atm}} \mathrm{x}_{\text {Air }}+\mathrm{f}_{\mathrm{S}}$

It should be noticed that equations (15) - (18) have been written in such a way that $\mathrm{n}_{\mathrm{CC}}, \mathrm{x}_{\mathrm{CO}_{2}}$ and $\mathrm{x}_{\mathrm{CH}_{4}}$ are independent variables, while, $\mathrm{x}_{\mathrm{CO}}, \mathrm{x}_{\mathrm{H}_{2}}, \mathrm{x}_{\mathrm{H}_{2} \mathrm{O}}$ and $\mathrm{x}_{\mathrm{T}}$ are dependent variables.

The First Law of Thermodynamics was applied to the global gasification reaction, and the resulting expression is presented in equation (22). There is no work crossing the boundaries of the system, and changes in kinetic and potential energy are negligible.

$1 \mathrm{~mol}_{\text {Bio }} \Delta \overline{\mathrm{h}}_{\text {React }}^{\mathrm{o}}=\mathrm{H}_{\mathrm{P}}^{\mathrm{o}}-\mathrm{H}_{\mathrm{R}}^{\mathrm{o}}$

where:

$$
\begin{aligned}
\mathrm{H}_{\mathrm{P}}^{\mathrm{o}}= & \left(1-\mathrm{n}_{\mathrm{CC}}\right) \overline{\mathrm{h}}_{\mathrm{C}}^{\mathrm{o}}+\mathrm{x}_{\mathrm{H}_{2}} \overline{\mathrm{h}}_{\mathrm{H}_{2}}^{\mathrm{o}}+\mathrm{x}_{\mathrm{CO}} \overline{\mathrm{h}}_{\mathrm{CO}}^{\mathrm{o}}+\mathrm{x}_{\mathrm{CO}_{2}} \overline{\mathrm{h}}_{\mathrm{CO}_{2}}^{\mathrm{o}}+\mathrm{x}_{\mathrm{CH}_{4}} \overline{\mathrm{h}}_{\mathrm{CH}_{4}}^{\mathrm{o}} \\
& +\mathrm{x}_{\mathrm{H}_{2} \mathrm{O}} \overline{\mathrm{h}}_{\mathrm{H}_{2} \mathrm{O}}^{\mathrm{o}}+\left(\frac{\mathrm{f}_{\mathrm{N}}}{2}+\rho_{\mathrm{atm}} \mathrm{x}_{\mathrm{Air}}\right) \overline{\mathrm{h}}_{\mathrm{N}_{2}}^{\mathrm{o}}+\mathrm{f}_{\mathrm{S}} \overline{\mathrm{h}}_{\mathrm{SO}_{2}}^{\mathrm{o}}+\mathrm{f}_{\mathrm{Ash}} \overline{\mathrm{h}}_{\mathrm{SiO}_{2}}^{\mathrm{o}}
\end{aligned}
$$

$\mathrm{H}_{\mathrm{R}}^{\mathrm{o}}=\mathrm{H}_{\text {Bio }}^{\mathrm{o}}+\mathrm{x}_{\text {Steam }} \overline{\mathrm{h}}_{\mathrm{H}_{2} \mathrm{O}}^{\mathrm{o}}+\mathrm{x}_{\text {Air }} \overline{\mathrm{h}}_{\mathrm{O}_{2}}^{\mathrm{o}}+\mathrm{x}_{\text {Air }} \rho_{\mathrm{atm}} \overline{\mathrm{h}}_{\mathrm{N}_{2}}^{\mathrm{o}}+\mathrm{x}_{\mathrm{Oxy}} \overline{\mathrm{h}}_{\mathrm{O}_{2}}^{\mathrm{o}}$

$\mathrm{T}_{\text {Steam }}, \mathrm{T}_{\text {Air }}$ and $\mathrm{T}_{\text {Oxy }}$ are the inlet temperatures of steam, air and oxygen, respectively, which are used to evaluate their enthalpies. The gasification temperatures $\left(\mathrm{T}_{\mathrm{Gas}}\right)$ are provided in the experimental works and they are used to determine the enthalpies of the products.

In order to complete the system of equation for determining the number of moles of the products at the gasification temperature $\mathrm{T}_{\mathrm{Gas}}$, the chemical equilibrium condition was applied. Three reactions have been commonly adopted to model the equilibrium composition of the gasification in fluidized bed gasifiers. These reactions are the methane formation reaction (MFR) [18,19,30-32], water-gas homogeneous reaction (WGHR) [7,8,19,33,34] and methane reforming reaction (MRR) [19,32,33], which are shown in equations (25) - (27), respectively.

$$
\begin{array}{ll}
\mathrm{C}+2 \mathrm{H}_{2} \Leftrightarrow \mathrm{CH}_{4} & \left(\Delta \overline{\mathrm{h}}_{\text {React }}^{\mathrm{O}}=-74.8 \mathrm{~kJ} / \mathrm{mol}\right) \\
\mathrm{CO}+\mathrm{H}_{2} \mathrm{O} \Leftrightarrow \mathrm{H}_{2}+\mathrm{CO}_{2} \quad\left(\Delta \overline{\mathrm{h}}_{\text {React }}^{\mathrm{o}}=-41.1 \mathrm{~kJ} / \mathrm{mol}\right) \\
\mathrm{CH}_{4}+\mathrm{H}_{2} \mathrm{O} \Leftrightarrow 3 \mathrm{H}_{2}+\mathrm{CO} \quad\left(\Delta \overline{\mathrm{h}}_{\text {React }}^{\mathrm{o}}=206.1 \mathrm{~kJ} / \mathrm{mol}\right)
\end{array}
$$

The chemical equilibrium constants obtained from the reactions presented above are shown in equations (28) - (30), respectively $[1,35,36]$.

$$
\begin{aligned}
& \mathrm{K}_{\mathrm{MFR}}=\frac{\mathrm{X}_{\mathrm{CH}_{4}} \mathrm{x}_{\mathrm{T}}}{\left(\mathrm{X}_{\mathrm{H}_{2}}\right)^{2}}\left(\frac{\mathrm{P}_{\mathrm{Gas}}}{\mathrm{P}_{\mathrm{O}}}\right)^{-1} \\
& \mathrm{~K}_{\mathrm{WGHR}}=\frac{\mathrm{x}_{\mathrm{CO}_{2}} \mathrm{x}_{\mathrm{H}_{2}}}{\mathrm{x}_{\mathrm{CO}} \mathrm{X}_{\mathrm{H}_{2} \mathrm{O}}} \\
& \mathrm{K}_{\mathrm{MRR}}=\frac{\mathrm{x}_{\mathrm{CO}}\left(\mathrm{x}_{\mathrm{H}_{2}}\right)^{3}}{\mathrm{x}_{\mathrm{CH}_{4}} \mathrm{x}_{\mathrm{H}_{2} \mathrm{O}}\left(\mathrm{x}_{\mathrm{T}}\right)^{2}}\left(\frac{\mathrm{P}_{\mathrm{Gas}}}{\mathrm{P}_{\mathrm{O}}}\right)^{2}
\end{aligned}
$$

Generally, the gasification pressure $\left(\mathrm{P}_{\mathrm{Gas}}\right)$ in fluidized bed gasifiers is equal to the normal pressure $\left(\mathrm{P}_{\mathrm{o}}\right)$, thus the ratio of gasification pressure to normal pressure might have no effect on equations (28) and (30).

\subsection{Optimization method to obtain correction factors}

There are different studies which present advances regarding the calculation of the correction factors. These studies are briefly described below.

In the work by Loha et al. [7] the adjustment of the chemical equilibrium model was made by multiplying the chemical equilibrium constants of the methane formation reaction and the homogenous water-gas reaction by the correction factors of 0.93 and 0.71 , respectively. In this way, average RMS error over six samples of syngas composition was decreased from an initial value of approximately 3.34 to a final value of 2.62 .

In the work by Jarungthammachote and Dutta [10] correction factors with values 11.28 and 0.91 were multiplied to the chemical equilibrium constants of the methane formation and homogeneous water-gas reactions, respectively. This adjustment was made to approximate the modified chemical equilibrium model to the experimental data, being the factor 11.28 and 0.91 necessary to adjust the concentration of $\mathrm{CH}_{4}$ and $\mathrm{CO}$, respectively.

In the work by Barman et al. [12] the correction factor of the chemical equilibrium constant of the methane formation reaction was calculated by increasing in steps of 0.5 a correction factor that was initially 1 . At the end of this process, the correction factor selected was 3.5. For the homogeneous water-gas reaction, a 
correction factor was not included due to the high gasification temperature, instead it was considered that this reaction reaches chemical equilibrium.

In the work by Mendiburu et al. [13] the adjustment of the chemical equilibrium constants of the methane formation and homogenous water-gas reactions was performed. The correction factor of the methane formation reaction was obtained by adjusting the model to the experimental data of the selected works. A similar process determined the correction factor of the homogeneous water-gas reaction.

In the work by Lim and Lee [37], empirical relations (based on the ER parameter) were used to calculate the correction factors for the methane formation and homogeneous water-gas formation reactions.

\subsubsection{The objective functions}

As aforementioned, the correction factors are used to better approximate the experimental syngas composition using chemical equilibrium models. In other works, these correction factors have been obtained by trial and error without relying in any analytical method for their calculation [7,10-13]. In the present work, the correction factors have been determined through an optimization

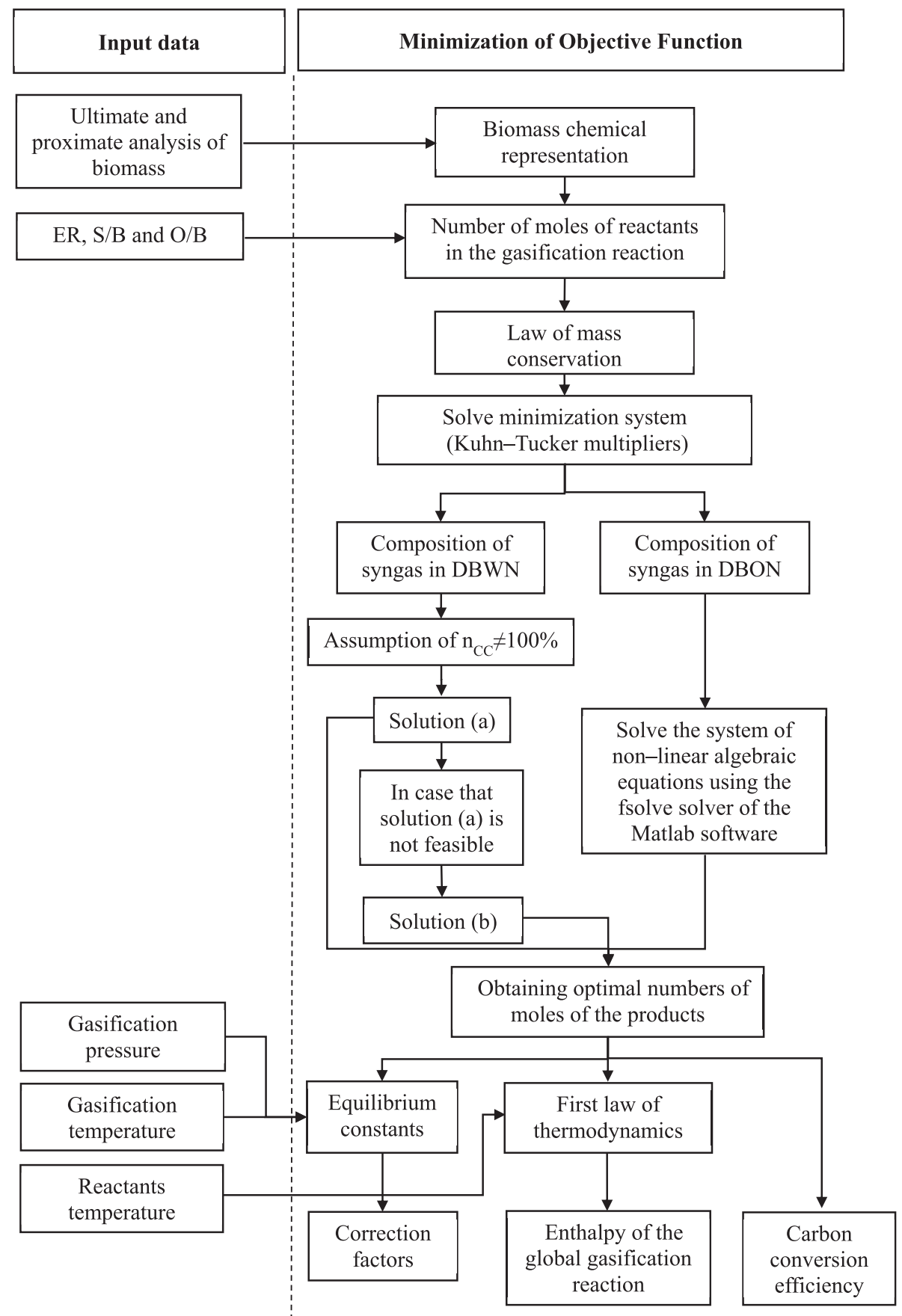

Fig. 2. Optimization method solution scheme. 
method which uses the Kuhn-Tucker multipliers [38-42]. The procedure followed in this section is depicted in Fig. 2.

The proposed method consists in the minimization of an objective function that is derived from the definition of RMS error [9]. The objective function depends on the number of moles of syngas $\left(\mathrm{x}_{\mathrm{Syn}}\right)$ derived from the experimental composition reported in scientific articles.

The syngas composition is generally given in dry basis with nitrogen (DBWN) or dry basis without nitrogen (DBON). DBWN is mostly used when air is the gasifying agent, while DBON is generally used when steam or oxygen are the gasifying agents. Therefore, the number of moles of syngas $\left(\mathrm{x}_{\mathrm{Syn}}\right)$ is different from the total number of moles of gases $\left(\mathrm{x}_{\mathrm{T}}\right)$, because the later considers the number of moles of steam $\left(\mathrm{x}_{\mathrm{H}_{2} \mathrm{O}}\right)$ and sulfur dioxide $\left(\mathrm{f}_{\mathrm{S}}\right)$ present in the products while the former does not. The experimental concentration of the species "i" $\left(\mathrm{H}_{2}, \mathrm{CO}, \mathrm{CO}_{2}, \mathrm{CH}_{4}\right.$ or $\left.\mathrm{N}_{2}\right)$ is defined by equation (31).

$\mathrm{EP}_{\mathrm{i}} \%=\frac{100 \mathrm{x}_{\mathrm{i}}}{\mathrm{X}_{\mathrm{Syn}}} \%$

The number of moles of syngas, $\mathrm{x}_{\mathrm{Syn}}$, in DBWN is given by equation (32). On the other hand, the value of $\mathrm{x}_{\text {Syn }}$ in $\mathrm{DBON}$ is given in equation (33).

$\mathrm{x}_{\mathrm{Syn}}=\frac{100\left(\frac{\mathrm{f}_{\mathrm{N}}}{2}+\rho_{\mathrm{atm}} \mathrm{x}_{\text {Air }}\right)}{\mathrm{EP}_{\mathrm{N}_{2}}}$

$\mathrm{x}_{\mathrm{Syn}}=\mathrm{C}_{\mathrm{H}_{2}}+2 \mathrm{n}_{\mathrm{CC}}+\mathrm{x}_{\mathrm{CO}_{2}}-3 \mathrm{x}_{\mathrm{CH}_{4}}$

The RMS error obtained is presented in equation (34) being " $n$ " the number of species of the syngas. Hence, the objective functions obtained for DBWN and DBON are given by equations (35) and (36), respectively.

$\mathrm{RMS}=\sqrt{\frac{\sum_{\mathrm{i}=1}^{\mathrm{n}}\left(E P_{\mathrm{i}} \mathrm{x}_{\mathrm{Syn}}-100 \mathrm{x}_{\mathrm{i}}\right)^{2} \mathrm{x}_{\mathrm{Syn}}^{-2}}{\mathrm{n}}}$

Objective function for $D B W N$

$$
\begin{aligned}
\mathrm{F}_{\mathrm{Obj}}\left(\mathrm{n}_{\mathrm{CC}}, \mathrm{x}_{\mathrm{CO}_{2}}, \mathrm{x}_{\mathrm{CH}_{4}}\right) & =: \mathrm{F}_{\mathrm{Obj}} \\
& =\sum_{\mathrm{i}=\mathrm{H}_{2}, \mathrm{CO}, \mathrm{CO}_{2}, \mathrm{CH}_{4}, \mathrm{~N}_{2}}\left(\mathrm{EP}_{\mathrm{i}} \mathrm{x}_{\mathrm{Syn}}-100 \mathrm{x}_{\mathrm{i}}\right)^{2}
\end{aligned}
$$

Objective function for DBON

$$
\begin{aligned}
\mathrm{F}_{\mathrm{Obj}}\left(\mathrm{n}_{\mathrm{CC}}, \mathrm{x}_{\mathrm{CO}_{2}}, \mathrm{x}_{\mathrm{CH}_{4}}\right) & =: \mathrm{F}_{\mathrm{Obj}} \\
& =\sum_{\mathrm{i}=\mathrm{H}_{2}, \mathrm{CO}_{\mathrm{CO}}, \mathrm{CH}_{4}}\left(\mathrm{EP}_{\mathrm{i}} \mathrm{x}_{\mathrm{Syn}}-100 \mathrm{x}_{\mathrm{i}}\right)^{2} \mathrm{x}_{\mathrm{Syn}}^{-2}
\end{aligned}
$$

The independent variables of the objective functions have their domains defined in $[0,1]$. On the other hand, the co-domains of the objective functions are defined in $\mathrm{R}$ (set of real numbers). It is important to mention that the objective function for DBWN and DBON are a strictly convex and a convex function, respectively.

\subsubsection{Optimization using Kuhn-Tucker multipliers}

In the present section the variables $\mathrm{n}_{\mathrm{CC}}, \mathrm{x}_{\mathrm{CO}_{2}}$ and $\mathrm{x}_{\mathrm{CH}_{4}}$ have been substituted by $\alpha_{1}, \alpha_{2}$ and $\alpha_{3}$, respectively. It is important to mention that the optimization that uses the Kuhn-Tucker multipliers is the generalization of the Lagrange multipliers optimization method. Thus, in order to perform an optimization using the Kuhn-Tucker multipliers $(\mu)$ it is essential to define the Lagrangian expression (L) with inequality constraints obtained from the domains of independent variables $\left(\mathrm{n}_{\mathrm{CC}}, \mathrm{x}_{\mathrm{CO}_{2}}\right.$ and $\mathrm{x}_{\mathrm{CH}_{4}}$ ). The Lagrangian expression is shown in equation (37). While, the independent variables have to satisfy the inequality constraints, obtained from their domains, presented in equation (38).

$\mathrm{L}=\mathrm{F}_{\mathrm{Obj}}+\sum_{\mathrm{i}=1}^{3} \mu_{\mathrm{i}}\left(\alpha_{\mathrm{i}}-1\right)-\sum_{\mathrm{i}=1}^{3} \mu_{\mathrm{i}+3} \alpha_{\mathrm{i}}$

$0 \leq \alpha_{\mathrm{i}}, \alpha_{\mathrm{i}} \leq 1$ and $\mu_{\mathrm{j}} \geq 0$ for $\mathrm{i}=1$ to 3 and $\mathrm{j}=1$ to 6

The Karush-Kuhn-Tucker conditions [38-42] were applied to equation (37) obtaining six equations (Complementarity constraints) which are the following: $\mu_{\mathrm{i}}\left(\alpha_{\mathrm{i}}-1\right)=0$ and $\mu_{\mathrm{i}+3} \alpha_{\mathrm{i}}=0$ for $\mathrm{i}=1$ to 3 . Notice that the conditions stablish that $0 \leq \alpha_{\mathrm{i}}$ and $\alpha_{\mathrm{i}} \leq 1$. From the experimental results $[7,8,14,16,17,19,23,25,28,29,43]$ it is known that the number of moles of $\mathrm{CO}, \mathrm{CO}_{2}$ and $\mathrm{CH}_{4}$ must be greater than zero. Among the different possibilities that can satisfy the equations, some were discarded, for instance, it was discarded that:

a) $\alpha_{2}=1$ or $\alpha_{3}=1$.

b) $\alpha_{2}=0$ or $\alpha_{3}=0$.

c) $\alpha_{1}=0$.

Therefore, some of the Kuhn-Tucker multipliers could be obtained which are shown in equation (39).

$\mu_{\mathrm{i}+1}=0$ for $\mathrm{i}=1$ to 5

Substituting the values of the Kuhn-Tucker multipliers, shown in equation (39), into the system of equations obtained from the Lagrangian expression, the result is the system shown in equations $(40)-(42)$.

$\frac{\partial \mathrm{F}_{\mathrm{Obj}}}{\partial \alpha_{1}}+\mu_{1}=0$

$\frac{\partial \mathrm{F}_{\text {Obj }}}{\partial \alpha_{\mathrm{i}+1}}=0$ for $\mathrm{i}=1$ to 2

$\mu_{1}\left(\alpha_{1}-1\right)=0$

This system of equations is limited by the inequalities presented in equation (38), but knowing that equation (39) is also satisfied.

Now the objective functions for DBWN [equation (35)] and for DBON [equation (36)] are replaced in equations (40) and (41) to then solve the system of equations (40) - (42).

In the case of the objective function for DBWN there are two possible solutions: (a) for the case in which $\mu_{1}=0$ and $\mathrm{n}_{\mathrm{CC}} \neq 100 \%$, and, (b) for the case in which $\mu_{1} \neq 0$ and $n_{\mathrm{CC}}=100 \%$. Then, for the solution (a) the values of $\mathrm{n}_{\mathrm{CC}}, \mathrm{x}_{\mathrm{CO}_{2}}$ and $\mathrm{x}_{\mathrm{CH}_{4}}$ are determined by the equations (43) - (45). On the other hand, for solution (b) the value of $\mathrm{n}_{\mathrm{CC}}=100 \%$ is replaced into equations (44) and (45). The number of moles of the other species can be obtained from the mass balance given in equations (15) - (18). The solution (a) is preferred over the solution (b) because the $\mathrm{n}_{\mathrm{CC}} \neq 100 \%$. 
$\mathrm{n}_{\mathrm{CC}}=\frac{\left(\mathrm{EP}_{\mathrm{H}_{2}}+9 \mathrm{EP}_{\mathrm{CO}}+8 \mathrm{EP}_{\mathrm{CO}_{2}}+12 \mathrm{EP}_{\mathrm{CH}_{4}}\right)\left(\frac{\mathrm{f}_{\mathrm{N}}}{2}+\rho_{\mathrm{atm}} \mathrm{x}_{\mathrm{Air}}\right) \mathrm{EP}_{\mathrm{N}_{2}}^{-1}-\mathrm{C}_{\mathrm{H}_{2}}}{10}$

$\mathrm{x}_{\mathrm{CO}_{2}}=\frac{8 \mathrm{n}_{\mathrm{CC}}-5 \mathrm{C}_{\mathrm{H}_{2}}+\left(5 \mathrm{EP}_{\mathrm{H}_{2}}+11 \mathrm{EP}_{\mathrm{CO}_{2}}+2 \mathrm{EP}_{\mathrm{CH}_{4}}-13 \mathrm{EP}_{\mathrm{CO}}\right)\left(\frac{\mathrm{f}_{\mathrm{N}}}{2}+\rho_{\mathrm{atm}} \mathrm{x}_{\mathrm{Air}}\right) \mathrm{EP}_{\mathrm{N}_{2}}^{-1}}{29}$

$\mathrm{x}_{\mathrm{CH}_{4}}=\frac{12 \mathrm{n}_{\mathrm{CC}}+7 \mathrm{C}_{\mathrm{H}_{2}}+\left(2 \mathrm{EP}_{\mathrm{CO}_{2}}+3 \mathrm{EP}_{\mathrm{CH}_{4}}-7 \mathrm{EP}_{\mathrm{H}_{2}}-5 \mathrm{EP} \mathrm{CO}_{\mathrm{CO}}\right)\left(\frac{\mathrm{f}_{\mathrm{N}}}{2}+\rho_{\mathrm{atm}} \mathrm{x}_{\mathrm{Air}}\right) \mathrm{EP}_{\mathrm{N}_{2}}^{-1}}{29}$

In the case of the objective function for DBON the solution was obtained by using the fsolve solver of the Matlab software [44-46]. The values obtained for $\mathrm{n}_{\mathrm{CC}}, \mathrm{x}_{\mathrm{CO}_{2}}$ and $\mathrm{x}_{\mathrm{CH}_{4}}$ were then replaced into equations (15) - (18) to determine the number of moles of the other species in the products.

The correction factors for the chemical equilibrium constants of the three chemical reactions $[8,19,33]$ presented in equations $(25)-$ (27) are denoted by $f_{M F R}, f_{W G H R}$ and $f_{M R R}$, respectively. The expressions for determination of the correction factors are presented in equations (46) - (48). The number of moles of the species in equations (46) - (48) are those determined in the solutions for DBWN and DBON.

$\mathrm{f}_{\mathrm{MFR}}=\frac{\mathrm{X}_{\mathrm{CH}_{4}} \mathrm{X}_{\mathrm{T}}\left(\frac{\mathrm{P}_{\mathrm{Gas}}}{\mathrm{P}_{\mathrm{o}}}\right)^{-1}}{\mathrm{~K}_{\mathrm{MFR}} \mathrm{X}_{\mathrm{H}_{2}}^{2}}$

$\mathrm{f}_{\mathrm{WGHR}}=\frac{\mathrm{x}_{\mathrm{CO}_{2}} \mathrm{x}_{\mathrm{H}_{2}}}{\mathrm{~K}_{\mathrm{WGHR}} \mathrm{X}_{\mathrm{CO}} \mathrm{X}_{\mathrm{H}_{2} \mathrm{O}}}$
$\mathrm{f}_{\mathrm{MRR}}=\frac{\mathrm{x}_{\mathrm{CO}}\left(\mathrm{x}_{\mathrm{H}_{2}}\right)^{3}\left(\frac{\mathrm{P}_{\mathrm{Gas}}}{\mathrm{P}_{\mathrm{o}}}\right)^{2}}{\mathrm{~K}_{\mathrm{MRR}} \mathrm{X}_{\mathrm{CH}_{4}} \mathrm{x}_{\mathrm{H}_{2} \mathrm{O}} \mathrm{x}_{\mathrm{T}}^{2}}$

The correction factors were determined using the data taken from several experimental articles [7,8,14,16,17,19,23,25,28,29,43]. The $f_{\text {MFR }}$ was found to be on the interval [2.4044, 1236.3325], the $\mathrm{f}_{\mathrm{WGHR}}$ on the interval $[0.0990,2.2639]$ and $\mathrm{f}_{\mathrm{MRR}}$ on the interval $\left[3.9033 \times 10^{-07}, 0.6015\right]$. As can be observed the interval of $f_{W G H R}$ is not so small nor so large with respect to the intervals of $f_{M F R}$ and $f_{\text {MRR }}$. Therefore, the $f_{W G H R}$ was selected for the modeling process which is going to be presented in the next section.

It is also important to point out that it is not recommendable to simply use the experimental syngas composition and obtain the number of moles of the species in the products. That is because the value of $n_{C C}$ and the composition of the solid residue are not reported in most experimental articles.

Finally, the enthalpy of reaction $\Delta \overline{\mathrm{h}}_{\text {React }}^{\mathrm{O}}$ is determined with equation (22) by considering in the products the number of moles of each component as determined by the optimization method.

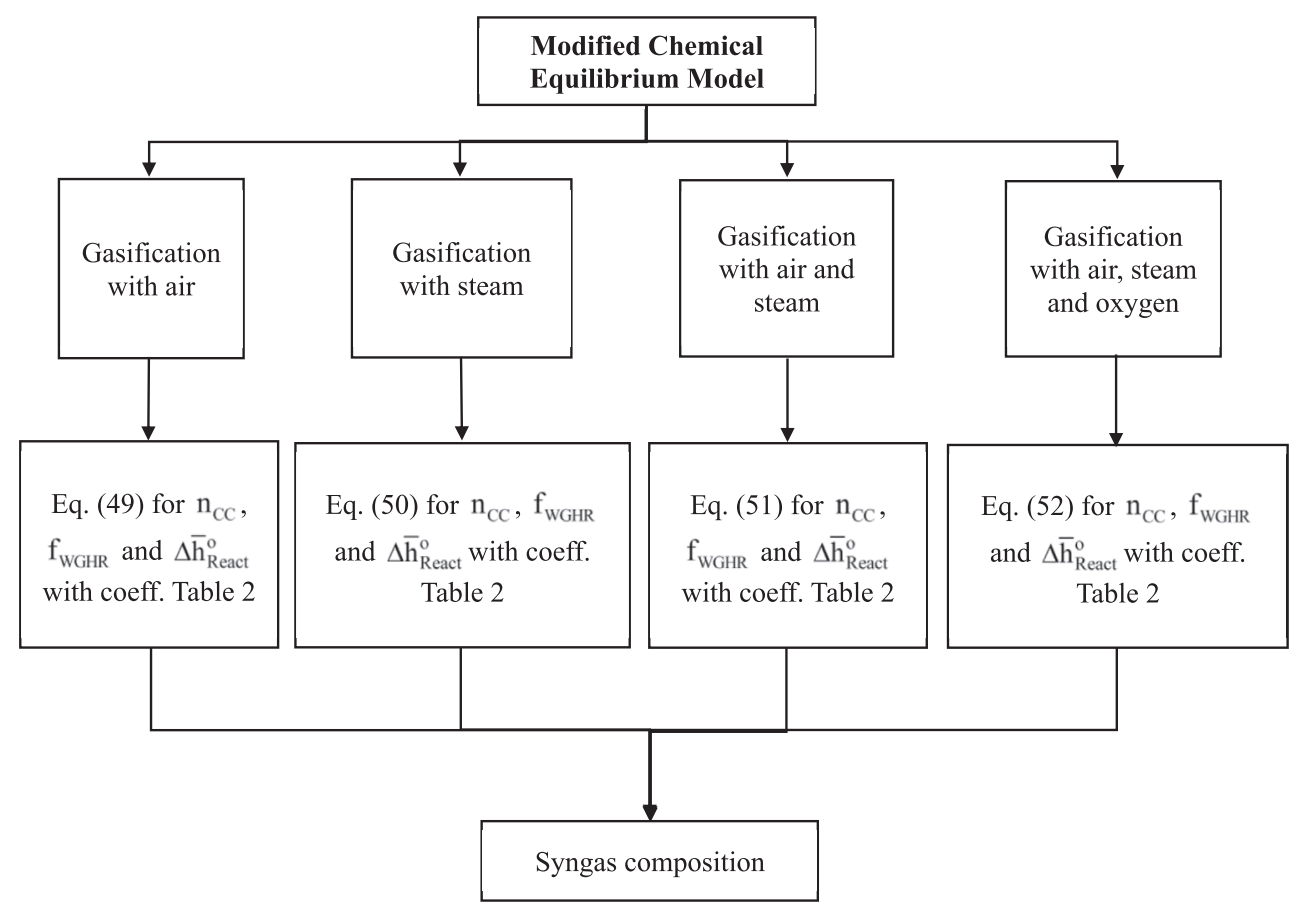

Fig. 3. Modified chemical equilibrium model solution scheme. 
Table 1

Distribution of selected experimental compositions of syngas.

\begin{tabular}{lccc}
\hline Gasifying agent & References & $\begin{array}{c}\text { Number of } \\
\text { data }\end{array}$ & $\begin{array}{c}\text { Number of data for } \\
\text { validation }\end{array}$ \\
\hline Air & {$[8,14,16,43]$} & 28 & 5 \\
Steam & {$[7,19,25]$} & 17 & 4 \\
Air and steam & {$[17,23,28,29]$} & 20 & 5 \\
Air, steam and oxygen & {$[23]$} & 11 & 2 \\
\hline
\end{tabular}

\section{Modified chemical equilibrium model}

The proposed modified chemical equilibrium model consists of three correlations for the following parameters: carbon conversion efficiency $\left(\mathrm{n}_{\mathrm{CC}}\right)$, correction factor $\left(\mathrm{f}_{\mathrm{WGHR}}\right)$ and enthalpy of the global gasification reaction $\left(\Delta \overline{\mathrm{h}}_{\text {React }}^{\mathrm{O}}\right)$. These magnitudes were replaced in a system of two equations that is constituted by: The First Law of Thermodynamics and the modified chemical equilibrium equation for the homogeneous water-gas reaction [equation (53)]. The proposed correlations are related to the values obtained from the substitution of the optimal numbers of moles for the theoretical composition of the syngas. To calculate these optimal numbers of moles, the objective functions based on the definition of the RMS error were minimized. A disadvantage of the proposed modified chemical equilibrium model is the assumption that the tar is not present in the products of the proposed global gasification reaction. This assumption was made due to the small production of tar which is generally obtained from fluidized bed gasifiers.

These three correlations were obtained by applying linear regressions [47]. The solution scheme for the modified chemical equilibrium model is depicted in Fig. 3.

Seventy-six samples of syngas compositions from different experimental articles were selected [7,8,14,16,17,19,23,25,28,29,43]. The gasification agents were air, steam, air-steam, and air-steam-oxygen. The set of 76 samples was divided into a set containing 60 samples and another set with 16 samples. The first one was used to obtain the correlations for $\mathrm{n}_{\mathrm{CC}}, \mathrm{f}_{\mathrm{WGHR}}$ and $\Delta \overline{\mathrm{h}}_{\text {React }}^{\mathrm{O}}$ while the second one was used to validate the modified chemical equilibrium model. The samples used for the validation were proportionally selected from each type of gasifying agent or agents. Table 1 presents the distribution of the number of samples adopted to develop each modified chemical equilibrium model. The modified chemical equilibrium model introduces three correlated values through one of the equations (49), (50), (51) or (52), which should be used together with the coefficients provided in Table 2. The obtained correlations are shown below.

Gasification with air

$$
\begin{aligned}
\mathrm{Z}=\mathrm{I} & +\mathrm{C}_{1} \mathrm{f}_{\text {Ash }}+\mathrm{C}_{2} \mathrm{f}_{\text {Moist }}+\mathrm{C}_{3} \mathrm{e}^{\mathrm{x}}+\mathrm{C}_{4}\left(\frac{\mathrm{f}_{\text {Moist }}}{\mathrm{f}_{\text {Ash }}}\right)+\mathrm{C}_{5} \mathrm{ER} \\
& +\mathrm{C}_{6} \mathrm{ER}^{2}+\mathrm{C}_{7} \mathrm{~T}_{\text {Gas }}
\end{aligned}
$$

Gasification with steam

It was assumed that carbon conversion efficiency $\left(\mathrm{n}_{\mathrm{CC}}\right)$ is $100 \%$ because this value has always been obtained for all the optimization method's calculations.

$$
\begin{aligned}
\mathrm{Z}=\mathrm{I} & +\mathrm{C}_{1}\left(\frac{\mathrm{f}_{\text {Moist }}}{\mathrm{f}_{\text {Ash }}}\right)+\mathrm{C}_{2}(\mathrm{~S} / \mathrm{B})+\mathrm{C}_{3}(\mathrm{~S} / \mathrm{B})^{2}+\mathrm{C}_{4}(\mathrm{~S} / \mathrm{B})^{3} \\
& +\mathrm{C}_{5}\left(\frac{\mathrm{T}_{\text {Steam }}}{\mathrm{T}_{\text {Gas }}}\right)+\mathrm{C}_{6} \mathrm{~T}_{\text {Gas }}
\end{aligned}
$$

Gasification with air-steam

$$
\begin{aligned}
\mathrm{Z}=\mathrm{I} & +\mathrm{C}_{1} \mathrm{f}_{\text {Ash }}+\mathrm{C}_{2} \mathrm{f}_{\text {Moist }}+\mathrm{C}_{3} \mathrm{ER}+\mathrm{C}_{4}(\mathrm{~S} / \mathrm{B})+\mathrm{C}_{5}\left(\frac{\mathrm{T}_{\text {Air }}}{\mathrm{T}_{\text {Gas }}}\right) \\
& +\mathrm{C}_{6}\left(\frac{\mathrm{T}_{\text {Steam }}}{\mathrm{T}_{\text {Gas }}}\right)
\end{aligned}
$$

Gasification with air-oxygen-steam

In this case the carbon conversion efficiency $\left(\mathrm{n}_{\mathrm{CC}}\right.$ ) was also assumed to be $100 \%$ because this value has always been obtained for all the optimization method's calculations.

$$
\begin{aligned}
& \mathrm{Z}= \mathrm{I} \\
&+\mathrm{C}_{1} \mathrm{ER}+\mathrm{C}_{2} \mathrm{ER}(\mathrm{S} / \mathrm{B})+\mathrm{C}_{3}[\mathrm{ER}(\mathrm{S} / \mathrm{B})]^{2}+\mathrm{C}_{4}(\mathrm{O} / \mathrm{B}) \\
&+\mathrm{C}_{5}(\mathrm{O} / \mathrm{B})^{2}+\mathrm{C}_{6} \mathrm{~T}_{\text {Gas }}
\end{aligned}
$$

The value of $100 \%$ was adopted for carbon conversion efficiency when using the correlations for the carbon conversion efficiency presented in equations (49) and (51) exceeds $100 \%$.

$\mathrm{f}_{\text {WGHR }} \mathrm{K}_{\mathrm{WGHR}}=\frac{\mathrm{x}_{\mathrm{CO}_{2}} \mathrm{x}_{\mathrm{H}_{2}}}{\mathrm{x}_{\mathrm{CO}} \mathrm{X}_{\mathrm{H}_{2} \mathrm{O}}}$

For the calculation of the composition of the syngas using the modified chemical equilibrium model, the values obtained by the

\begin{tabular}{|c|c|c|c|c|c|c|c|c|c|c|c|c|}
\hline \multirow[t]{4}{*}{ Coefficients } & \multicolumn{12}{|c|}{ Gasifying agent } \\
\hline & \multicolumn{3}{|c|}{ Air } & \multicolumn{3}{|c|}{ Steam } & \multicolumn{3}{|c|}{ Air and steam } & \multicolumn{3}{|c|}{ Air, steam and oxygen } \\
\hline & \multicolumn{3}{|c|}{$\mathrm{Z}=\mathrm{Eq} .(49)$} & \multicolumn{3}{|c|}{$\mathrm{Z}=\mathrm{Eq} \cdot(50)$} & \multicolumn{3}{|c|}{$\mathrm{Z}=\mathrm{Eq} .(51)$} & \multicolumn{3}{|c|}{$\mathrm{Z}=\mathrm{Eq} \cdot(52)$} \\
\hline & $\begin{array}{l}\mathrm{n}_{\mathrm{CC}} \\
(\%)\end{array}$ & $\mathrm{f}_{\mathrm{WGHR}}$ & $\begin{array}{c}\Delta \overline{\mathrm{h}}_{\text {React }}^{\mathrm{O}} \\
(\mathrm{kJ} / \mathrm{mol})\end{array}$ & $\begin{array}{l}\mathrm{n}_{\mathrm{CC}} \\
(\%)\end{array}$ & $\mathrm{f}_{\mathrm{WGHR}}$ & $\begin{array}{c}\Delta \overline{\mathrm{h}}_{\text {React }}^{\mathrm{O}} \\
(\mathrm{kJ} / \mathrm{mol})\end{array}$ & $\begin{array}{l}\mathrm{n}_{\mathrm{CC}} \\
(\%)\end{array}$ & $\mathrm{f}_{\mathrm{WGHR}}$ & $\begin{array}{c}\Delta \overline{\mathrm{h}}_{\text {React }}^{\mathrm{O}} \\
(\mathrm{kJ} / \mathrm{mol})\end{array}$ & $\begin{array}{l}\mathrm{n}_{\mathrm{CC}} \\
(\%)\end{array}$ & $f_{\text {WGHR }}$ & $\begin{array}{c}\Delta \overline{\mathrm{h}}_{\text {React }}^{\mathrm{O}} \\
(\mathrm{kJ} / \mathrm{mol})\end{array}$ \\
\hline $\mathrm{x}$ & $\mathrm{f}_{\text {Moist }}$ & $\mathrm{f}_{\text {Ash }}$ & $\mathrm{f}_{\text {Moist }}$ & - & - & - & - & - & - & - & - & - \\
\hline I & -2979.4090 & -522.3036 & -2241.0450 & 100 & 7.3278 & -143.3802 & 111.4569 & -6.7994 & 124.7102 & 100 & 0.6108 & 117.0359 \\
\hline $\mathrm{C}_{1}$ & 402.3987 & -550.5976 & 84.4509 & 0 & 0.0104 & -0.7079 & 13.2464 & -21.4213 & -1038.5164 & 0 & 0.0000 & -468.2000 \\
\hline $\mathrm{C}_{2}$ & -3391.6953 & 0.5249 & -1903.5383 & 0 & -20.7697 & 39.8212 & -537.7031 & 48.2313 & 765.7268 & 0 & 0.7189 & 0.0000 \\
\hline $\mathrm{C}_{3}$ & 3042.3198 & 519.8738 & 2139.1648 & 0 & 18.4715 & -6.5110 & 157.4910 & 1.4444 & -277.8947 & 0 & 0.0530 & 0.0000 \\
\hline $\mathrm{C}_{4}$ & -10.8580 & -0.0124 & -11.5510 & 0 & -5.1779 & 0.0000 & 24.1496 & 0.1007 & 49.2069 & 0 & -15.5142 & -229.5642 \\
\hline$C_{5}$ & 76.2600 & 14.7958 & -303.1547 & 0 & 2.4434 & 0.0000 & -115.0108 & 8.5565 & 65.7674 & 0 & 37.9479 & 0.0000 \\
\hline $\mathrm{C}_{6}$ & 0.0000 & -16.3996 & 0.0000 & 0 & 0.0000 & 0.3416 & 44.0283 & -3.6423 & -354.1102 & 0 & 0.0016 & 0.0205 \\
\hline$C_{7}$ & -0.0212 & 0.0004 & 0.1789 & - & - & - & - & - & - & - & - & - \\
\hline $\mathrm{R}^{2}$ & 0.9662 & 0.9030 & 0.9877 & 1 & 0.9700 & 0.9862 & 0.9643 & 0.8843 & 0.9978 & 1 & 0.6676 & 0.9833 \\
\hline
\end{tabular}
model have to be substituted in the system of two equations conformed by the application of the First Law of Thermodynamics [equation (22)] and the modified chemical equilibrium equation for the homogenous water-gas reaction [equation (53)]. The solution of this system of equations are the number of moles of methane and

Table 2

Coefficients for correlations shown in equations (49) - (52). 
Table 3

Gasification conditions for the application of the optimization method.

\begin{tabular}{lccccc}
\hline Exp. & Reference & ER & S/B & O/B & $\mathrm{T}_{\text {Gas }}\left({ }^{\circ} \mathrm{C}\right)$ \\
\hline 1 & Sarker et al. [43] & 0.30 & 0.00 & 0.00 & 876 \\
2 & Arteaga-Pérez et al. [16] & 0.34 & 0.00 & 0.00 & 803.5 \\
3 & Karmakar et al. [8] & 0.45 & 0.00 & 0.00 & 600 \\
4 & Radmanesh et al. [14] & 0.66 & 0.00 & 0.00 & 800 \\
5 & Karmakar and Datta [19] & 0.00 & 1.70 & 0.00 & 750 \\
6 & Loha et al. [7] & 0.00 & 1.32 & 0.00 & 690 \\
7 & Vecchione et al. [25] & 0.00 & 1.00 & 0.00 & 830 \\
8 & Campoy et al. [28] & 0.23 & 0.18 & 0.00 & 752 \\
9 & Loha et al. [17] & 0.35 & 0.80 & 0.00 & 850 \\
10 & Sethupathy Subbaiah et al. [29] & 0.18 & 0.30 & 0.00 & 650 \\
11 & Campoy et al. [23] & 0.27 & 0.43 & 0.00 & 755 \\
12 & Campoy et al. [23] & 0.36 & 0.32 & $0.1728^{\mathrm{a}}$ & 808 \\
\hline
\end{tabular}

a Value obtained by using the oxygen flow of $1.5 \mathrm{Nm}^{3} / \mathrm{h}$ provided by the authors.

carbon dioxide. Finally, we will proceed to calculate the other chemical substances using the equations of conservation of the mass presented in equations (15) - (17).

\section{Results and discussions}

All the syngas experimental compositions selected for the application of the optimization method are presented in Tables S1 to S4 of the supplementary material. The number of moles obtained by applying the optimization method are presented in Tables S5 to S8. The correction factors, enthalpies of reaction and the Kuhn-Tucker multipliers $\left(\mu_{1}\right)$ are shown in Tables S9 to S12. Finally, the theoretical compositions of the syngas when the optimization method is applied are presented in Tables S13 to S16.

For some experimental articles [28,29,43] considered in the present study it was assumed that the percentage of nitrogen was the difference between $100 \%$ and the concentrations of $\mathrm{H}_{2}, \mathrm{CO}, \mathrm{CO}_{2}$ and $\mathrm{CH}_{4}$ present in the products of the global gasification reaction [equation (10)].

The syngas composition was obtained by applying the input parameters shown in Table 3, which are the same input parameters reported in the experimental articles considered for the present study.

Table 4 shows the syngas composition obtained from the optimization method application. These compositions are very close to experimental ones, as expected. It can be observed from Table 4 that the calculated syngas compositions are closer to the experimental compositions when air is used as gasifying agent. Other information regarding the optimization method is presented in Table 5, where the enthalpies of reaction, correction factors and Kuhn-Tucker multipliers $\left(\mu_{1}\right)$ are reported.

In order to analyze the values of the enthalpies of reaction $\left(\Delta \overline{\mathrm{h}}_{\text {React }}^{\mathrm{O}}\right)$ with respect to each gasifying agent presented in Table 5 , it is important to notice that a negative value of the enthalpy of reaction means that the process has liberated heat (exothermic).

In the case of gasification with air, it can be observed in Table 5 that the increase of ER produces a decrease on the value of $\Delta \overline{\mathrm{h}}_{\text {React }}^{\mathrm{O}}$, which means that more exothermic reactions are taking place due to the increase of the available oxygen.

In the case of the gasification with steam, it can be observed in Table 5 that an increase of S/B produces an increase of $\Delta \overline{\mathrm{h}}_{\text {React }}^{\mathrm{O}}$, which means that more endothermic reactions are taking place. In the case of gasification with steam there is more hydrogen available

Table 4

Results obtained from the optimization using different gasifying agents.

\begin{tabular}{|c|c|c|c|c|c|c|c|c|}
\hline Exp. & Reference & $\begin{array}{l}\mathrm{H}_{2} \\
(\%)\end{array}$ & $\begin{array}{l}\mathrm{CO} \\
(\%)\end{array}$ & $\begin{array}{l}\mathrm{CO}_{2} \\
(\%)\end{array}$ & $\begin{array}{l}\mathrm{CH}_{4} \\
(\%)\end{array}$ & $\begin{array}{l}\mathrm{N}_{2} \\
(\%)\end{array}$ & RMS error from this work & RMS error from the reference \\
\hline 1 & Sarker et al. [43] & 3.82 & 13.15 & 13.23 & 3.14 & 66.66 & 0.88 & - \\
\hline 2 & Arteaga-Pérez et al. [16] & 5.85 & 15.23 & 14.14 & 5.13 & 59.65 & 1.08 & - \\
\hline 3 & Karmakar et al. [8] & 9.56 & 11.08 & 21.66 & 3.55 & 54.15 & 0.90 & 1.21 \\
\hline 4 & Radmanesh et al. [14] & 4.60 & 11.25 & 14.47 & 0.50 & 69.19 & 0.33 & - \\
\hline 5 & Karmakar and Datta [19] & 51.15 & 18.23 & 26.57 & 4.04 & 0.00 & 1.41 & 3.62 \\
\hline 6 & Loha et al. [7] & 49.43 & 15.53 & 29.14 & 5.90 & 0.00 & 2.02 & 2.12 \\
\hline 7 & Vecchione et al. [25] & 49.17 & 19.17 & 22.13 & 9.53 & 0.00 & 1.19 & - \\
\hline 8 & Campoy et al. [28] & 14.60 & 13.80 & 16.90 & 5.20 & 49.50 & 0.00 & - \\
\hline 9 & Loha et al. [17] & 13.00 & 14.30 & 20.50 & 2.80 & 49.40 & 0.09 & - \\
\hline 10 & Sethupathy Subbaiah et al. [29] & 21.22 & 15.78 & 15.96 & 6.26 & 40.78 & 0.95 & - \\
\hline 11 & Campoy et al. [23] & 31.20 & 22.90 & 35.80 & 10.20 & 0.00 & 0.00 & - \\
\hline 12 & Campoy et al. [23] & 27.40 & 34.20 & 34.60 & 3.80 & 0.00 & 3.70 & - \\
\hline
\end{tabular}

Table 5

Correction factors and enthalpy of reaction obtained from the optimization method.

\begin{tabular}{|c|c|c|c|c|c|c|c|c|}
\hline Exp. & ER & S/B & $\mathrm{O} / \mathrm{B}$ & $\begin{array}{c}\Delta \overline{\mathrm{h}}_{\text {React }}^{\mathrm{o}} \\
(\mathrm{kJ} / \mathrm{mol})\end{array}$ & $\mathrm{f}_{\mathrm{MFR}}$ & $\mathrm{f}_{\text {WGHR }}$ & $\mathrm{f}_{\mathrm{MRR}}$ & $\mu_{1}$ \\
\hline 1 & 0.30 & 0.00 & 0.00 & -2.17 & 1236.33 & 0.1257 & $3.90 \times 10^{-07}$ & 0.00 \\
\hline 2 & 0.34 & 0.00 & 0.00 & -3.87 & 507.15 & 0.0990 & $2.81 \times 10^{-06}$ & 0.00 \\
\hline 3 & 0.45 & 0.00 & 0.00 & -63.40 & 9.24 & 0.9887 & 0.0643 & 0.00 \\
\hline 4 & 0.66 & 0.00 & 0.00 & -153.00 & 59.18 & 0.3546 & $6.39 \times 10^{-05}$ & 0.00 \\
\hline 5 & 0.00 & 1.70 & 0.00 & 159.90 & 3.81 & 0.6681 & 0.0042 & 22.07 \\
\hline 6 & 0.00 & 1.32 & 0.00 & 134.01 & 2.71 & 0.8819 & 0.0206 & 32.93 \\
\hline 7 & 0.00 & 1.00 & 0.00 & 124.12 & 16.64 & 1.2020 & 0.0007 & 7.18 \\
\hline 8 & 0.23 & 0.18 & 0.00 & -14.16 & 43.39 & 0.4464 & $3.04 \times 10^{-04}$ & 0.00 \\
\hline 9 & 0.35 & 0.80 & 0.00 & 21.13 & 85.94 & 0.3690 & $1.65 \times 10^{-05}$ & 0.00 \\
\hline 10 & 0.18 & 0.30 & 0.00 & 95.75 & 8.09 & 0.2923 & $1.31 \times 10^{-02}$ & 0.00 \\
\hline 11 & 0.27 & 0.43 & 0.00 & -17.41 & 37.83 & 0.5716 & $2.77 \times 10^{-04}$ & 0.00 \\
\hline 12 & 0.36 & 0.32 & $0.1728^{a}$ & -75.96 & 30.59 & 0.4940 & $2.61 \times 10^{-04}$ & 339.93 \\
\hline
\end{tabular}

\footnotetext{
a Using the oxygen flow of $1.5 \mathrm{Nm}^{3} / \mathrm{h}$ provided by the authors, this quantity is obtained.
} 
Table 6

Validation of modified chemical equilibrium model applied to fluidized bed gasification.

\begin{tabular}{|c|c|c|c|c|c|c|c|c|c|c|c|c|}
\hline Reference & ER & $\mathrm{S} / \mathrm{B}$ & $\begin{array}{l}\text { Oxygen flow rate } \\
\left(\mathrm{Nm}^{3} / \mathrm{h}\right)\end{array}$ & $\mathrm{O} / \mathrm{B}^{\mathrm{a}}$ & $\mathrm{T}_{\text {Gas }}\left({ }^{\circ} \mathrm{C}\right)$ & $\begin{array}{l}\mathrm{n}_{\mathrm{CC}} \\
(\%)\end{array}$ & $\begin{array}{l}\mathrm{H}_{2} \\
(\%)\end{array}$ & $\begin{array}{l}\mathrm{CO} \\
(\%)\end{array}$ & $\begin{array}{l}\mathrm{CO}_{2} \\
(\%)\end{array}$ & $\begin{array}{l}\mathrm{CH}_{4} \\
(\%)\end{array}$ & $\begin{array}{l}\mathrm{N}_{2} \\
(\%)\end{array}$ & RMS \\
\hline Karmakar et al. [8] & 0.35 & 0.00 & 0.00 & 0.00 & 700 & 82.68 & 14.63 & 22.47 & 16.67 & 1.32 & 44.91 & \\
\hline Predictive model & 0.35 & 0.00 & 0.00 & 0.00 & 700 & 94.32 & 15.09 & 19.31 & 17.05 & 1.75 & 46.80 & 1.68 \\
\hline Radmanesh et al. [14] & 0.32 & 0.00 & 0.00 & 0.00 & 805 & - & 9.20 & 16.20 & 12.70 & 2.50 & 59.60 & \\
\hline Predictive model & 0.32 & 0.00 & 0.00 & 0.00 & 805 & 71.58 & 13.56 & 14.01 & 15.00 & 2.40 & 55.03 & 3.16 \\
\hline Arteaga-Pérez et al. [16] & 0.34 & 0.00 & 0.00 & 0.00 & 801.5 & - & 5.40 & 16.18 & 13.67 & 3.54 & 60.49 & \\
\hline Predictive model & 0.34 & 0.00 & 0.00 & 0.00 & 801.5 & 76.43 & 8.31 & 12.99 & 15.63 & 4.53 & 58.55 & 2.33 \\
\hline Sarker et al. [43] & 0.35 & 0.00 & 0.00 & 0.00 & 874 & - & 3.84 & 14.31 & 14.98 & 2.67 & 64.20 & \\
\hline Predictive model & 0.35 & 0.00 & 0.00 & 0.00 & 874 & 63.11 & 5.69 & 11.26 & 15.01 & 2.99 & 65.04 & 1.65 \\
\hline Karmakar and Datta [19] & 0.00 & 1.32 & 0.00 & 0.00 & 650 & 84.10 & 47.25 & 11.25 & 31.90 & 9.60 & 0.00 & \\
\hline Predictive model & 0.00 & 1.32 & 0.00 & 0.00 & 650 & 100.00 & 48.49 & 11.69 & 32.31 & 7.51 & 0.00 & 1.25 \\
\hline Loha et al. [7] & 0.00 & 1.00 & 0.00 & 0.00 & 750 & - & 49.50 & 23.70 & 21.20 & 5.60 & 0.00 & \\
\hline Predictive model & 0.00 & 1.00 & 0.00 & 0.00 & 750 & 100.00 & 46.71 & 27.87 & 20.73 & 4.69 & 0.00 & 2.56 \\
\hline Vecchione et al. [25] & 0.00 & 0.70 & 0.00 & 0.00 & 830 & - & 47.93 & 21.11 & 22.81 & 8.15 & 0.00 & \\
\hline Predictive model & 0.00 & 0.70 & 0.00 & 0.00 & 830 & 100.00 & 46.91 & 21.84 & 20.64 & 10.61 & 0.00 & 1.76 \\
\hline Campoy et al. [28] & 0.19 & 0.28 & 0.00 & 0.00 & 727 & 89.00 & 16.20 & 11.50 & 18.60 & 5.90 & 47.80 & \\
\hline Predictive model & 0.19 & 0.28 & 0.00 & 0.00 & 727 & 60.57 & 16.60 & 11.00 & 19.60 & 6.60 & 46.20 & 0.94 \\
\hline Loha et al. [17] & 0.35 & 0.50 & 0.00 & 0.00 & 750 & 71.90 & 9.20 & 12.80 & 20.80 & 2.10 & 55.10 & \\
\hline Predictive model & 0.35 & 0.50 & 0.00 & 0.00 & 750 & 79.61 & 10.90 & 14.30 & 20.40 & 1.70 & 52.70 & 1.50 \\
\hline Sethupathy Subbaiah et al. [29] & 0.18 & 0.30 & 0.00 & 0.00 & 750 & 81.37 & 20.92 & 17.56 & 16.41 & 4.50 & 40.61 & \\
\hline Predictive model & 0.18 & 0.30 & 0.00 & 0.00 & 750 & 67.43 & 21.93 & 17.20 & 14.83 & 5.52 & 40.51 & 0.97 \\
\hline Campoy et al. [23] & 0.25 & 0.31 & 1.40 & 0.1235 & 781 & 96.00 & 31.60 & 32.90 & 24.90 & 10.60 & 0.00 & \\
\hline Predictive model & 0.25 & 0.31 & 1.40 & 0.1235 & 781 & 100.00 & 34.70 & 36.30 & 24.60 & 4.50 & 0.00 & 3.82 \\
\hline Campoy et al. [23] & 0.24 & 0.58 & 1.00 & 0.1190 & 765 & 96.00 & 34.30 & 23.50 & 31.30 & 10.90 & 0.00 & \\
\hline Predictive model & 0.24 & 0.58 & 1.00 & 0.1190 & 765 & 100.00 & 38.40 & 28.80 & 28.30 & 4.60 & 0.00 & 4.84 \\
\hline
\end{tabular}

a This magnitude is calculated according to the theoretical development proposed in this work.

for the gasification reaction; however, it is necessary to provide more heat to the reaction by means of an electric furnace, for example.

The gasification with air-steam mixtures show a more complicated behavior in Table 5 . We can analyze this behavior by considering experiments 8,9 and 10 in Table 5. It is observed that for the experiment 8 the exothermic reactions dominate since $\Delta \overline{\mathrm{h}}_{\text {React }}^{\mathrm{o}}$ is negative, then, for experiment 9 the values of ER and S/B are increased and the endothermic reactions dominate since $\Delta \overline{\mathrm{h}}_{\text {React }}^{\mathrm{O}}$ is positive. An interesting comparison appear when we consider experiment 8 and 10 , in which $\mathrm{ER}_{8}>\mathrm{ER}_{10}, \mathrm{~S} / \mathrm{B}_{8}<\mathrm{S} / \mathrm{B}_{10}$ and the endothermic reactions dominate since $\Delta \overline{\mathrm{h}}_{\text {React }}^{\mathrm{C}}$ positive $\left(\Delta \overline{\mathrm{h}}_{\text {React, } 8}^{\mathrm{O}}<\Delta \overline{\mathrm{h}}_{\text {React,10 }}^{\mathrm{O}}\right)$. Therefore, there should be an optimum value of ER and S/B for which the exothermic reactions dominate (less external heat is needed) and at the same time the $\mathrm{H}_{2}$ concentration in the syngas is adequate.

For the gasification with air-steam-oxygen, it is observed in Table 5 that the $\Delta \overline{\mathrm{h}}_{\text {React }}^{\mathrm{O}}$ is negative; thus, we can conclude that the presence of oxygen enhances the combustion processes.

It can also be observed in Table 5 , that the correction factors $\mathrm{f}_{\mathrm{MFR}}$ and $f_{M R R}$ present wider intervals than the correction factor $f_{W G H R}$ which was selected for the modification of the chemical equilibrium model, this was also explained in section 2 .

In Table 6 are shown the syngas compositions obtained from the modified chemical equilibrium model. For the gasification with air, steam and air-steam it is observed that the composition is accurately determined. However, the calculation of the carbon conversion efficiency is not as satisfactory, because in several cases the calculated value is higher than the experimental value. The reason for this might be that the modified chemical equilibrium model does not consider tars and, therefore, assumes a higher carbon conversion.

For the gasification with air-steam-oxygen the determination of the syngas concentration is not as accurate as in the other cases. On the other hand, the experimental carbon conversion efficiency presents a value of $96 \%$, and the modified chemical equilibrium model assumes a value of $100 \%$ for these mixture of gasification agents. The presence of oxygen in the gasification agents enhances the combustion reactions, thus, consuming more carbon.

Finally, with respect to the RMS error, it is considered that the modified chemical equilibrium model determines with very good accuracy the composition of the syngas. In the best cases the RMS is lower than 1 and it is always lower than 5 .

\section{Conclusion}

The optimization method developed by using the Kuhn-Tucker multipliers was applied to analytically determine the values of the correction factors for the chemical equilibrium constants. While other authors have determined these correction factors empirically they were determined analytically in the present work. With the number of moles obtained from the application of the optimization method, very low RMS errors are obtained, in some cases equal to 0 .

Three correlations were proposed for the modification of a chemical equilibrium model. These correlations were obtained for the correction factor, the enthalpy of reaction and the carbon conversion efficiency. A set of three correlations was obtained for each gasification agent considered, namely, air, steam, air-steam and air-steam-oxygen.

The modified chemical equilibrium model was applied to several biomasses and validated with experimental data, showing very good accuracy for the determination of the syngas composition.

\section{Appendix A. Supplementary data}

Supplementary data related to this article can be found at https://doi.org/10.1016/j.energy.2018.03.141.

\section{References}

[1] Basu P. Biomass Gasification and Pyrolysis. first ed. New York: Elsevier; 2010.

[2] Souza-Santos MLd. Solid fuels combustion and gasification. second ed. New York: CRC Press; 2010.

[3] Higman C, van der Burgt M. Gasification. second ed. New York: Elsevier; 2003. 
[4] Basu P. Combustion and gasification in fluidized beds. first ed. United States: Taylor \& Francis; 2006

[5] Spliethoff H. Power Generation from Solid Fuels. first ed. Berlin Heidelberg: Springer-Verlag; 2010.

[6] Brown RC, editor. Thermochemical Processing of Biomass. first ed. Great Britain: John Wiley \& Sons; 2011.

[7] Loha C, Chatterjee PK, Chattopadhyay H. Performance of fluidized bed steam gasification of biomass - Modeling and experiment. Energy Convers Manag 2011:52:1583-8.

[8] Karmakar MK, Mandal J, Haldar S, Chatterjee PK. Investigation of fuel gas generation in a pilot scale fluidized bed autothermal gasifier using rice husk. Fuel 2013;111:584-91.

[9] Devore JL, Berk KN. Modern mathematical statistics with applications. Second. New York: Springer; 2012.

[10] Jarungthammachote S, Dutta A. Thermodynamic equilibrium model and second law analysis of a downdraft waste gasifier. Energy 2007:32:1660-9.

[11] Vaezi M, Passandideh-Fard M, Moghiman M, Charmchi M. Gasification of heavy fuel oils: A thermochemical equilibrium approach. Fuel 2011;90: 878-85.

[12] Barman NS, Ghosh S, De S. Gasification of biomass in a fixed bed downdraft gasifier - A realistic model including tar. Bioresour Technol 2012;107:505-11.

[13] Mendiburu AZ, Carvalho Jr JA, Coronado CJR. Thermochemical equilibrium modeling of biomass downdraft gasifier: Stoichiometric models. Energy 2014;66:189-201.

[14] Radmanesh R, Chaouki J, Guy C. Biomass Gasification in a Bubbling Fluidized Bed Reactor: Experiments and Modeling. AIChE J 2006;52:4258-72.

[15] Zheng H, Morey RV. An unsteady-state two-phase kinetic model for corn stover fluidized bed steam gasification process. Fuel Process Technol 2014; $124: 11-20$.

[16] Arteaga-Pérez LE, Casas-Ledón Y, Pérez-Bermúdez R, Peralta LM, Dewulf J Prins W. Energy and exergy analysis of a sugar cane bagasse gasifier integrated to a solid oxide fuel cell based on a quasi-equilibrium approach. Chem Eng J 2013;228:1121-32.

[17] Loha C, Chattopadhyay H, Chatterjee PK. Energy generation from fluidized bed gasification of rice husk. J Renew Sustain Energy 2013:5.

[18] Loha C, Chattopadhyay H, Chatterjee PK. Thermodynamic analysis of hydrogen rich synthetic gas generation from fluidized bed gasification of rice husk. Energy 2011;36:4063-71.

[19] Karmakar MK, Datta AB. Generation of hydrogen rich gas through fluidized bed gasification of biomass. Bioresour Technol 2011;102:1907-13.

[20] McBride BJ, Zehe MJ, Gordon S. NASA glenn coefficients for calculating thermodynamic properties of individual species. 2002. p. 286.

[21] Mendiburu AZ, Carvalho Jr JA, Zanzi R, Coronado CR, Silveira JL. Thermochemical equilibrium modeling of a biomass downdraft gasifier: Constrained and unconstrained non-stoichiometric models. Energy 2014;71:624-37.

[22] Channiwala SA, Parikh PP. A unified correlation for estimating HHV of solid, liquid and gaseous fuels. Fuel 2002;81:1051-63.

[23] Campoy M, Gómez-Barea A, Vidal FB, Ollero P. Air-steam gasification of biomass in a fluidised bed: Process optimisation by enriched air. Fuel Process Technol 2009;90:677-85.

[24] Rapagnà S, Jand N, Kiennemann A, Foscolo PU. Steam-gasification of biomass in a fluidised-bed of olivine particles. Biomass and Bioenergy 2000;19: 187-97.

[25] Vecchione L, Moneti M, Cocchi S, Villarini M, Sisinni M, Micangeli A. Parametric experimental tests of steam gasification of pine wood in a fluidized bed reactor. J Agric Eng 2013;44:587-90.

[26] Natarajan E, Baskara Sethupathy S. Gasification of Groundnut Shells. Energy Sources, Part A Recov Util Environ Eff 2015;37:980-6.

[27] Serrano D, Kwapinska M, Horvat A, Sánchez-Delgado S, Leahy JJ. Cynara cardunculus L. gasification in a bubbling fluidized bed: The effect of magnesite and olivine on product gas, tar and gasification performance. Fuel 2016;173: 247-59.

[28] Campoy M, Gómez-Barea A, Villanueva AL, Ollero P. Air-Steam Gasification of Biomass in a Fluidized Bed under Simulated Autothermal and Adiabatic Conditions. Ind Eng Chem 2008;47:5957-65.

[29] Sethupathy Subbaiah B, Kumar Murugan D, Babu Deenadayalan D, D. Ml Gasification of Biomass Using Fluidized Bed. Int J Innov Res Sci Eng Techno 2014:3:8995-9002

[30] Liu Z, Peng W, Motahari-Nezhad M, Shahraki S, Beheshti M. Circulating fluidized bed gasification of biomass for flexible end-use of syngas: a micro and nano scale study for production of bio-methanol. J Clean Prod 2016;129: 249-55.

[31] Rodriguez-Alejandro DA, Nam H, Maglinao Jr AL, Capareda SC, AguileraAlvarado AF. Development of a modified equilibrium model for biomass pilotscale fluidized bed gasifier performance predictions. Energy 2016;115: 1092-108.

[32] Tan W, Zhong Q. Simulation of hydrogen production in biomass gasifier by ASPEN PLUS. In: Power Energy Eng Conf (APPEEC), 2010 Asia-Pacific: 2010.

[33] Lv PM, Xiong ZH, Chang J, Wu CZ, Chen Y, Zhu JX. An experimental study on biomass air-steam gasification in a fluidized bed. Bioresour Technol 2004;95: 95-101.

[34] Maglinao Jr AL, Capareda SC, Nam H. Fluidized bed gasification of high tonnage sorghum, cotton gin trash and beef cattle manure: Evaluation of synthesis gas production. Energy Convers Manag 2015;105:578-87.

[35] Müller I, Müller WH. Fundamentals of Thermodynamics and Applications. first ed. Springer-Verlag Berlin Heidelberg; 2009.

[36] Borgnakke C, Sonntag RE. Fundamentals of Thermodynamics. seventh ed. U.S.A: John Wiley \& Sons; 2009.

[37] Lim Y, Lee U-D. Quasi-equilibrium thermodynamic model with empirical equations for air-steam biomass gasification in fluidized-beds. Fuel Process Technol 2014;128:199-210.

[38] Forst W. Hoffmann D. Optimization-Theory and Practice. first ed. New York: Springer-Verlag; 2010.

[39] Jahn J. Introduction to the Theory of Nonlinear Optimization. third ed. Berlin Heidelberg: Springer-Verlag; 2007.

[40] Lange K. Optimization. first ed. New York: Springer-Verlag: 2004.

[41] Rao SS. Engineering Optimization. fourth ed. John Wiley \& Sons; 2009.

[42] Sun W, Yuan Y- X. Optimization Theory and Methods. first ed. United States of America: Springer US; 2006.

[43] Sarker S, Arauzo J, Nielsen HK. Semi-continuous feeding and gasification of alfalfa and wheat straw pellets in a lab-scale fluidized bed reactor. Energy Convers Manag 2015;99:50-61.

[44] Otto S, Denier JP. An Introduction to Programming and Numerical Methods in MATLAB. first ed. U.S.A: Springer-Verlag London; 2005.

[45] Kiusalaas J. Numerical Methods in Engineering with MATLAB. New York: Cambridge University Press; 2005.

[46] Chapra SC, Canale RP. Numerical Methods for Engineers. fifth ed. Singapore: Mc Graw Hill; 2006.

[47] Montgomery DC. Design and Analysis of Experiments. fifth ed. John Wiley \& Sons; 2001. 